\title{
IMPLICATURES IN THE CONTEXT OF COMMUNICATIVE ACT
}

\author{
IMPLICATURAS NO CONTEXTO DO ATO DE COMUNICAÇÃO
}

IMPLICATURAS EN EL CONTEXTO DEL ACTO COMUNICATIVO

\author{
Farida Bizyanovna SITDIKOVA ${ }^{1}$ \\ Maria Vladimirovna ASMOLOVSKAYA ${ }^{2}$
}

\begin{abstract}
The article presents a study in the field of linguistic pragmatics and considers the implicitness problem with respect to the communication act. Extracting an implicature of an utterance is proved to be the main condition for successful speech act. The relevance of the article is determined by the fact that the implicitness problem has not been completely studied and still has a lot of aspects to explore. The classification of different kinds of implicatures supported by examples from fiction texts is given. Moreover, some statistic data relating to implicatures types and their frequency are provided. The article might be interesting for specialists developing problems of linguistic pragmatics, communication acts and implicitness.
\end{abstract}

KEYWORDS: Communicative act. Linguistic pragmatics. Implicit meaning. Implicature. Interpretation.

RESUMO: $O$ artigo apresenta um estudo no campo da pragmática linguística e considera o problema da implicitude no que diz respeito ao ato de comunicação. Extrair a implicatura de um enunciado é comprovadamente a principal condição para o sucesso do ato de fala. A relevância do artigo é determinada pelo fato de que o problema da implicitude não foi totalmente estudado e ainda possui muitos aspectos a serem explorados. É apresentada a classificação de diferentes tipos de implicaturas suportadas por exemplos de textos de ficção. Além disso, são fornecidos alguns dados estatísticos relativos aos tipos de implicaturas e sua frequência. O artigo pode ser interessante para especialistas em desenvolvimento de problemas de pragmática linguística, atos de comunicação e implicitude.

PALAVRAS-CHAVE: Ato comunicativo. Pragmática linguística. Significado implícito. Implicatura. Interpretação.

RESUMEN: El artículo presenta un estudio en el campo de la pragmática lingüistica y considera el problema de la implícitaidad con respecto al acto comunicativo. Se ha demostrado que extraer una impicatura de un enunciado es la condición principal para un acto de habla exitoso. La relevancia del artículo viene determinada por el hecho de que el problema de la implícita no ha sido completamente estudiado y aún tiene muchos aspectos por explorar. Se da la clasificación de diferentes tipos de implicaturas apoyada por ejemplos de textos de ficción.

${ }^{1}$ Kazan Federal University (KPFU), Kazan - Russia. Associate Professor of the Department of Foreign Languages. PhD in Linguistics. ORCID: https://orcid.org/0000-0001-9167-1069. E-mail: farida7777@yandex.ru

${ }^{2}$ Kazan Federal University (KPFU), Kazan - Russia. Senior Lecturer of the Department of Foreign Languages. ORCID: https://orcid.org/0000-0002-8355-1566. E-mail: asmolovskayamaria@yandex.ru 
Además, se proporcionan algunos datos estadísticos relacionados con los tipos de impicaturas y su frecuencia. El artículo puede resultar interesante para especialistas en desarrollo de problemas de pragmática lingüística, actos de comunicación e implícitaidad.

PALABRAS CLAVE: Acto comunicativo. Pragmática lingüística. Significado implícito. Implicatura. Interpretación.

\section{Introduction}

In the XXI century the way of studying language phenomena has changed drastically. Several decades ago linguistic phenomena used to be studied mainly from the grammar aspect. At present researchers apply use the complex approach using the results of psycholinguistics, cognitive linguistics, linguistic pragmatics etc. Before the advent of linguistic pragmatics, the language was considered as a kind of abstract system, not related to the real process of communication. Its emergence has led to a revolution in understanding the functioning of language and the way communication process occurs in natural languages. A linguistic pragmatic approach focuses on the relationship between the linguistic form and its communicative functions, taking into consideration the context and situation (THOMAS, 1995. p. 7).

The aim of our paper is to explore implicitness in the aspect of a communicative act, to take into consideration the utterance interpretation by the recipient in the communication act, to look into specifics of speech interaction and effective speech communication based on the postulates of Grice (1989) and the theory of relevance, as well as to determine the necessary conditions for a successful communicative act.

By communication, we mean the socially determined process of transmitting and perceiving information under conditions of interpersonal and mass communication through various channels using different means of communication.

By implicitness we understand the presence of implicit information, that is a kind of information which is suggested but not communicated directly ${ }^{3}$.

When transferring information in natural languages, it is impossible to avoid such language phenomenon as implicitness. Implicitness is inherent in all natural languages and enables to transfer the infinite amount of information through a finite code. Implicit way of transferring information also allows to transfer it in a more concise and economical way.

${ }^{3}$ Available: https://dictionary.cambridge.org/dictionary/english/implicit. Access: 10 Dec. 2020. 
The communicative-pragmatic approach takes a central position in modern linguistics. Linguistic pragmatics has given a new impetus to the study of implicitness. One of the most relevant areas of research in modern linguistic pragmatics is the study of indirect language forms chosen by speakers in a specific situation of dialogical communication, as well as factors contributing to drawing the meaning of the statement.

The article is the continuation of series of works considering the phenomenon of language implicitness (SITDIKOVA; KHISAMOVA; MUTIGULLINA, 2019; SITDIKOVA; EREMEYEVA; VALIEVA, 2017). We wanted to take a look at implicitness in the aspect of a communicative act and to explore the way how the meaning of the utterance is interpreted by the recipient during the communication act.

By communication, we mean the socially determined process of transmitting and perceiving information under conditions of interpersonal and mass communication through various channels using different means of communication. When we transmit information in natural languages, it is impossible to avoid such language phenomenon as implicitness. Implicitness is inherent in all natural languages and enables to transfer the infinite amount of information through a finite code. The implicit way of transferring information also allows to transfer it in a more concise and economical way.

\section{Methods}

As the theoretical basis of the article we have used the works of Grice (1975; 1989), Sperber and Wilson (1986), Jespersen (2006), Shendels (1977), Kolshansky (1980), Paducheva (2010), Pocheptsov (1987), Komissarov (2002) etc.

The process of transferring implicit information is based on the ability of communicative act participants to understand information expressed in a non-verbal way on the basis of the situation, context and their cognitive environment.

In our study, we use the theory of relevance that was created by Sperber and Wilson (1986). The authors of the theory argue that a statement in a speech act is similar to incentive that encourages the recipient to find knowledge from the cognitive environment and, based on this knowledge, to understand the meaning of the statement. The formation of meaning takes several stages, they are all associated with implicit meaning. You can consider implicit meaning as a meaning not expressed in words but implied between the lines. So, we can look at any utterance as at an incentive that stimulates the recipient to use their background to extract the hidden meaning from the utterance (KASHICHKIN, 2013, p. 9). 
The research methods were descriptive, comparative analyses and also statistical method.

To illustrate the ideas of the article we have used examples from English fiction (MAUGHAM, 2019; 2020; SALINGER, 2020).

\section{Results and discussion}

Communicants can express their ideas both in explicit and implicit way. In the process of communication, utterances often contain some implicitly expressed meaning, which is called implicit. From each statement one or several implicatures can be extracted, which are obtained by the recipient as a result of semantic implication. The recipient has to use their background knowledge, situation and context. Our study aims to consider the communicative act in connection with the concept of implicature, as well as to determine the types of implicatures and the details of their use in the language. We also want to explore the conditions for a successful communication act.

For the communicative act to be successful, it is necessary for the recipient of the utterance to understand the utterance, that is be able to extract implicit meaning from the expressed content.

In addition to this, the so-called postulates developed by Grice must be observed. Grice (1975) listed these postulates in his world-famous work. He named them as the principles of cooperation, quantity, quality, relevance and manner, which Grice (1975, p. 26-27) calls "maxims". But still, the main condition is the ability of the receiver to draw the utterance implicature.

Let us explain the process of drawing the implicature by giving an example from a wellknown book "Catcher in the Rye" by Salinger (2020, p. 26): "He never exactly broke your heart when he went back to his own room". The highlighted phrase means: nobody felt regret when he went back to his own room. The implication is based on understanding the phraseological unit to break one's heart.

Another example is provided from the novel "The Painted Veil" by Maugham (2019): "I expect he was upset. It was naturally a shock. It's a damned humiliating position for any man. He always looks a fool. Walter doesn't give me the impression of a fellow who'd care to wash a lot of dirty linen in public". 
From the examples above we can see the kind of implicitness which is based on the meanings of the certain language units, like phraseological units, figurative use of words, abbreviations, words meaning cultural realities etc.

We consider the knowledge of language as part of the cognitive environment of a person, that is, knowledge about the world.

The concept of "implicature" was first used in the works of Grice (1989, p. 43). He divided them into ordinary (he called them conventional), which are based on the meanings of words, and communicative ones, in which the meaning is derived on the basis of context and situation.

In our work we are using the terms proposed by Komissarov (2002) and divide implicatures into the following categories: 1) communicative (based on meanings of specific language units) and contextual ones (based on context and situation) corresponding to two types of implicitity: the first one is associated with the linguistic meaning of the statement, and the second one with its individual contextual meaning.

The examples above relate to communicative implicatures based on language knowledge of a native speaker, which can be described as language presuppositions.

Some scholars instead of the term "contextual" use the concept of conversational implicature (BENOTTI; BLACKBURN, 2014), which goes back to Grice's (1989) paper the "Logic and Conversation". In our opinion, this term completely coincides with the concept of 'contextual implicature' in meaning.

It should be noted that modern research reveals new types of implicatures. For example, Apresyan and Orlov (2020) have revealed a type of implicatures, called false ones. Examining newspaper headlines the authors found out that article authors often create headlines in such a way that readers may misunderstand them and when they start reading articles there is the effect of deceived expectation. The authors of the article named this type of implicatures false ones. These implicatures are based on the valences of words that are intentionally misused to make the reader extract the wrong meaning.

But we still believe that this case relates to implicatures of the second type, so we stick to the traditional classification.

According to the results of our study, contextual implicatures prevail in number by 2 times. We selected about 100 examples from English fiction that included implicatures. Less than one third of them (27\%) were communicative, the rest were contextual ones. 
Contextual implicatures, according to Komissarov (2002, p. 89-91), can be divided into real (substantive), logical and conventional, depending on the ratio of the general meaning and implicitness of the statement.

Real implicatures are based on the identity between the way the situation is described in the text and situations in real life. For example, pressing the brake means stopping the car, wearing a wedding ring means being married, etc.

Sometimes communicants have to make to make logical conclusions from the utterance in order to extract an implicature, for example: "Hey", I said. "I've read this same sentence about twenty times since you came in. Anybody else except Ackley would've taken the goddam hint" ${ }^{\prime 4}$. From this utterance it is clear that the highlighted phrase means: Ackley's presence distracts Holden from reading. To extract the implicature the recipient of the utterance needs to make a logical operation: reading twenty times $\rightarrow$ getting distracted. We can make this logical operation because of our life experience and background knowledge.

Conventional links between implicit and explicit meanings exist when the utterance relates to the situation that, for various reasons, is not called directly. Such implications are often associated with a description of a person's behavior, their gestures and facial expressions, the set of which is specific for each linguistic and cultural community. For example, nodding one's head for most nations means affirmation, but for a Bulgarian it means the opposite.

Euphemisms may be another example of conventional implications. In particular, in all languages there are euphemisms for the death of a person, in English the examples are: 'pass away', 'bit the dust' or 'kick the bucket' instead of 'die'. This kind of implicitness is understandable for native speakers, but it can definitely be a problem for language learners (KOZLOVA; KADYROVA; SAKHIBULLINA, 2019).

We have to note that not in all cases even native speakers can derive implicatures from an utterance, i.e., a communicative act is not always successful. A prerequisite for extracting the meaning from a statement is the mental work that participants must do, comparing the language content of the statement with the environment of communication and with their previous experience, knowledge of the language and also background knowledge, for example historical knowledge (GARAEVA et al., 2018)

By creating a statement, the speaker expects the listener to do this mental work and to extract the implicature from the statement. However, in the process of verbal communication, failures can occur, that is incomplete understanding or misunderstanding can take place. For

${ }^{4}$ Available: http://masterrussian.net/f49/catcher-rye-j-d-salinger-english-russian-12212. Access: 10 Dec. 2020. 
example, a communicant may not know the necessary language or lack some other information to extract the meaning. In other words, for successful drawing the implicit meaning of a statement a receptor needs both objective factors (the background, language and situation knowledge) and subjective ones (receptor's ability to extract the meaning).

Consider the following example from "The Narrow Corner" by Maugham (2020): "With his tousled hair, his clear skin and blue eyes [...] he looked like a young Bacchus in a Venetian picture". Describing the appearance of the young attractive character Fred Blake, the author compares him with the young Bacchus in the Venetian picture, this association will be clear to the educated reader, but perhaps some readers may not draw the implicit meaning.

Sometimes the participants of the communicative act cannot extract the implicit meaning. The inability to draw the implicature of an utterance can be explained by differences in communicants' cognitive base, misunderstanding context and situation or lack of logical and intellectual abilities of the communicants.

\section{Conclusions}

1. The notion of implicature which was first introduced by P. Grice has lead to further development of language studies. Two types of implicatures correspond to two main kinds of implicitness: the first one is based on the meaning of words forming the utterance and does not depend on the context. The second one is based upon the context, situation and background knowledge of communicants.

2. For a communication act to be successful, in addition to fulfilling Grice's postulates, one of the main conditions is the ability of the recipient to extract the implicature of the utterance.

3. All implicatures can be splitted into 2 main types - communicative and contextual. According to the results of our study, contextual implicatures prevail in number by more than 2 times.

4. By linguistic means used in utterances implicatures can be divided into objective, logical and conventional ones. In our research, $8 \%$ were objective implicatures, $29 \%$ logical ones and $63 \%$ conventional implicatures.

5. For successful extracting the implicature of an utterance, the information receiver needs both objective (background, language knowledge and knowledge of the situation), and subjective factors (ability of the recipient to extract the meaning). 
6. In the process of verbal communication, there may be some cases when, for some reason communicants cannot extract the meaning. The inability to extract the implicature can be explained by differences in communicants' cognitive base or lack of logical and intellectual abilities of communicants.

ACKNOWLEDGEMENTS: The work is performed according to the Russian Government Program of Competitive Growth of Kazan Federal University.

\section{REFERENCES}

APRESYAN, V. Y.; ORLOV, A. V. Semanticheskiye tipy implicatur i usloviya ih vozniknoveniya. 2020. Available: http://www.dialog21.ru/media/4583/apresjanvjuplusorlovav-012.pdf. Access: 10 Dec. 2020.

BENOTTI, L.; BLACKBURN, P. Context and implicature. 2014. Available: https://www.researchgate.net/publication/312676945_Context_and_Implicature. Access: 10 Dec. 2020.

GARAEVA, A. K. et al. Awareness of historical background as one of the factors of better language acquisition. International Journal of English Language and Literature Studies, v. 7, n. 1, p. 15-21, 2018.

GRICE, P. Logic and conversation. In: COLE, P.; MORGAN, J. L. (Eds.). Syntax and semantics. New York: Academic Press, 1975. v. 3, p. 41-58.

GRICE, P. Studies in the way of words. Harvard University Press, 1989.

JESPERSEN, O. The philosophy of grammar. Routledge, 2006.

KASHICHKIN, A. V. Implitzitnost v kontexte perevoda: dis. ... kand. filol. nauk: 10.02.20. Moscow, 2013.

KOLSHANSKY, T. V. Kontextnaya semantika. Moscow: Nauka, 1980.

KOMISSAROV, V. N. Sovremennoe prrevodovedeniye. Moscow: ETC, 2002.

KOZLOVA, Y. A.; KADYROVA, A. A.; SAKHIBULLINA, K. A. Problems of testing application in foreign language learning control. Humanities and Social Sciences Reviews, v. 7, n. 6, p. 53-59, 2019.

MAUGHAM, W. S. Narrow corner. 2020. Available:

https://gutenberg.ca/ebooks/maughamws-narrowcorner/maughamws-narrowcorner-00-h.html. Access: 10 Dec. 2020. 
MAUGHAM, W. S. The painted veil. 2019. Available: https://www.reads2019.com/paintedveil. Access: 10 Dec. 2020.

PADUCHEVA, E. V. Viskazivaniye i ego sootnesennost' s deistvitel'nostyu. Moscow: LKI, 2010.

POCHEPTSOV, G. G. Kommunikativniye aspekti semantiki. Kiev: Vishcha Shkola, 1987.

SALINGER, J. D. The catcher in the rye. 2020. Available:

http://masterrussian.net/f49/catcher-rye-j-d-salinger-english-russian-12212/. Access: 10 Dec. 2020.

SHELDELS, E. I. Implicitnost v grammatike. In: SHENDELS, E. I. Voprosy romanogermanskoy philologii. Sintaksicheskaya semantika: sbornik nauchnikh trudov MGPIIY imeni M.Toreza. Moscow, 1977. p. 37-45.

SITDIKOVA, F. B.; EREMEYEVA, G. R.; VALIEVA, G. F. Implicit negation in dialogue discourse. Journal of History Culture and Art Research, v. 6, n. 6, p. 175-181, 2017.

SITDIKOVA, F. B.; KHISAMOVA, V. N.; MUTIGULLINA, Z. A. Implicit negation in tatar phraseology. Journal of Sociology and Social Anthropology, v. 10, n. 4, p. 175-179, 2019.

SPERBER, D.; WILSON, D. Relevance. Inference and Implicature. In: SPERBER, D.; WILSON, D. Meaning and interpretation. Oxford, 1986. p. 43-75.

THOMAS, J. Meaning in interaction: an introduction to pragmatics. Longman, 1995.

\section{How to reference this article}

SITDIKOVA, F. B.; ASMOLOVSKAYA, M. V. Implicatures in the context of communicative act. Rev. EntreLínguas, Araraquara, v. 7, n. esp. 3, e021049, Sep. 2021. e-ISSN: 2447-3529. DOI: https://doi.org/10.29051/el.v7iesp.3.15707

Submitted: 10/01/2021

Required revisions: 20/03/2021

Approved: 23/06/2021

Published: 01/08/2021 